Marta Keil

\title{
PRAKTYKA CHOREOGRAFICZNA JAKO PRAKTYKA POLITYCZNA
}

W niniejszym tekście chciałabym zaproponować spojrzenie na praktykę choreograficzną jako na praktykę polityczną oraz przestrzeń działań krytycznych. W moim przekonaniu współczesna choreografia należy nie tylko do najbardziej fascynujących i najszybciej rozwijających się dziedzin sztuki, ale jest również obszarem formułowania i testowania rozmaitych strategii krytycznych, które mogą okazać się nadzwyczaj przydatne także w innych obszarach artystycznych. Mam tu na myśli przede wszystkim zapoczątkowany w XX wieku proces demokratyzacji tańca, polegający na uwalnianiu go $\mathrm{z}$ reżimu baletowej kodyfikacji (jak choćby w przypadku prac Rudolfa Labana czy Mary Wigman), stopniowym włączaniu codziennego ruchu w praktyki choreograficzne przez twórców i twórczynie związane z post-modern dance (Banes 2013), upowszechnianiu zarówno praktyk artystycznych choreografów, jak i narzędzi ich tworzenia (m.in. poprzez szerokie udostępnianie partytur i instrukcji, od grupy Fluxus i Cage'a do projektu Everybody's Toolbox) czy w końcu redefinicji ram sytuacji scenicznej (Cvejić 2014).

Wspominam o tym dlatego, że sama obserwuję choreografię z perspektywy teatralnej praktyki kuratorskiej i mam za sobą próbę (nieudaną) wprowadzenia tańca współczesnego jako stałego, równoprawnego elementu programu do teatru repertuarowego. Przyglądając się statusowi choreografii w obszarze sztuk performatywnych w Polsce i kibicując walce choreografów i tancerzy o autonomię, odnoszę jednocześnie wrażenie, że polski teatr repertuarowy w znakomitej większości zdaje się pozostawać doskonale impregnowany na narzędzia krytyczne wypracowywane na polu choreografii. $\mathrm{Z}$ mojego punktu widzenia problemu nie rozwiązuje coraz bardziej powszechne zatrudnianie choreografów do opracowania tzw. „ruchu scenicznego” w spektaklach. To, co wydaje się dzisiaj najciekawszym wyzwaniem, to po pierwsze, zaproszenie choreografów do pracy nad własnymi spektaklami w ramach programu danej instytucji (i niekoniecznie zamykanie ich w najmniejszej sali, jaką dysponuje teatr), po drugie - otwarcie struktury teatru w sposób, który umożliwiałby praktykom choreograficznym i teatralnym rzeczywisty spór, konflikt, dyskusję - także dotyczącą metod pracy. 
$\mathrm{Z}$ tej perspektywy chciałabym opowiedzieć o sposobach myślenia i procedurach pracy nad spektaklem Any Vujanović Take It or Make It, który został zrealizowany pod moją opieką kuratorską w kwietniu 2015 roku w Teatrze Polskim im. Hieronima Konieczki w Bydgoszczy. Opierając się na doświadczeniu pracy kuratorskiej i dramaturgicznej nad projektem, zaproponuję, by pomyśleć o choreografii jako praktyce politycznej, która umożliwia artystom i widzom testowanie rozmaitych społecznych modeli, przyglądanie się procesowi produkcji sztuki i przemyślenia na nowo zarówno obowiązujących w nim struktur, jak i relacji władzy.

Chciałabym przy tym podkreślić, że moim celem nie jest tutaj próba formułowania uniwersalnych rozwiązań - daleko mi do postrzegania choreografii jako wszechstronnego narzędzia, za pomocą którego można za jednym zamachem dokonać radykalnej zmiany w mechanizmach wytwarzania i odbioru teatru. Przeciwnie: wychodzę z założenia, że realna zmiana w ramach instytucji teatru repertuarowego jest dzisiaj możliwa, jeżeli będzie miała miejsce na wielu poziomach. Nie szukam wielkich bohaterskich narracji - tym, co interesuje mnie tutaj najbardziej, są strategie oporu ujawniające się w skali mikro. Dlatego proponuję wspólne przyjrzenie się procesowi pracy nad bydgoskim spektaklem w perspektywie krytyki instytucjonalnej, którą rozumiem jako krytyczne badanie nawyków, struktur i metod pracy w obrębie instytucji sztuki. Take It or Make It byłoby w tym ujęciu próbą pomyślenia o praktyce choreograficznej jako o narzędziu, które umożliwia testowanie rozmaitych modeli społecznych, kwestionowanie pozycji artysty i widza, redefiniowanie relacji władzy w ramach procesu pracy nad spektaklem oraz które stawia w centrum uwagi pytanie o podmiotowość twórców i odbiorców.

W czasie, gdy współpracowałam z Teatrem Polskim w Bydgoszczy - pod dyrekcją Pawła Wodzińskiego i Bartosza Frąckowiaka - jednym z podstawowych nurtów tematycznych, wokół których koncentrował się program instytucji, była demokracja: sposób jej rozumienia, możliwy kształt i formy funkcjonowania. $\mathrm{Z}$ mojej perspektywy interesujące wydawało się pytanie o demokrację w odniesieniu do metod i struktur pracy w teatrze repertuarowym. Stąd decyzja o zaproszeniu do współpracy Any Vujanović, jednej z najważniejszych badaczek oraz praktyczek sztuk performatywnych w Europie, która od lat zajmuje się politycznością teatru i choreografii oraz wzajemnym przenikaniem się polityki i sztuki w kontekście współczesnego społeczeństwa neoliberalnego. Interesowało mnie badanie regul dzisiejszej demokracji poprzez praktyki choreograficzne oraz próba zastosowania tychże do demokratyzacji procesu pracy w ramach instytucji teatralnej. Jednym z podstawowych założeń projektu było sprawdzenie, czy możliwe jest w teatrze mówienie o demokracji nie poprzez pokazywanie jej i reprezentowanie na scenie, ale poprzez zastosowanie jej do metod pracy nad spektaklem.

Stąd na pierwszy rzut oka karkołomny i bardzo dla teatru ryzykowny pomysł na strukturę i sposób pracy, który zaraz postaram się objaśnić. Spektakl 
powstawał w zespole złożonym z pięciorga wykonawców: serbskiego choreografa i performera Sašy Asenticia, reżyserki filmowej i artystki wizualnej Marty Popivody (oboje są stałymi współpracownikami Any Vujanović) oraz trojga aktorów wówczas na stałe związanych z Teatrem Polskim: Macieja Pesty, Soni Roszczuk i Piotra Wawra jr. Praca była podzielona na dwa etapy, każdy trwający trzy tygodnie: pierwszy służył omówieniu koncepcji, rozmowom na temat procesu demokratyzacji praktyk choreograficznych oraz wspólnemu wypracowaniu narzędzi do dalszej pracy. Pomysł, który zaproponowali Vujanović wraz z Popivodą i Asenticiem, polegał na oparciu struktury spektaklu o partyturę eksperymentalnego reżysera filmowego Heinza Emigholza. Score, na którym pracowaliśmy, pochodził z filmu Schenec Tady II z 1973 roku, przy czym został przepisany przez Martę Popivodę i Anę Vujanović na potrzeby pracy na scenie. O ile podstawowe założenia u Emigholza polegały na ściśle zdefiniowanym czasie i nieokreślonej, dowolnej przestrzeni, w naszym przypadku było dokładnie odwrotnie: mieliśmy jasno określoną przestrzeń pracy (mała scena TPB) i omal do ostatniej chwili niezdefiniowany czas.

Decyzja o skupieniu pracy wokół partytury wynikała z historii jej zastosowania w choreografii. Partytura, jako spisana (nagrana, narysowana) instrukcja, stała się narzędziem demokratyzacji tańca: każdy mógł skorzystać z udostępnionych przez choreografów narzędzi, by odtworzyć dany spektakl bądź stworzyć na jego bazie coś nowego. Poprzez zapis i upowszechnienie partytury (kolektyw Everybody's Toolbox zebrał ich dziesiątki) artyści i artystki odsłaniali metodę własnej pracy, zrywając tym samym z mitem natchnionego artysty, tworzącego w odosobnieniu. Vujanović zaznacza, że:

(... ) myśląc o partyturze jako narzędziu demokratyzacji tańca, postrzegam ją jako obszar (pracy) wspólny dla wszystkich zaangażowanych w proces przygotowania spektaklu i jego wykonywania. Jego obecność zmniejsza znaczenie rozmaitych intuicji czy uczuć choreografa bądź reżysera, neutralizuje pojęcie smaku, otwiera natomiast przestrzeń dla dyskusji, umożliwia dzielenie się przekonaniami, pomysłami, wrażeniami i uczuciami zarówno pomiędzy wspóltwórcami, jak i artystami oraz publicznością. Najważniejszym punktem odniesienia jest tutaj zatem polityczność formy tańca. Co szczególnie istotne, jej najważniejsze elementy - takie, jak ciało zwyczajne, codzienne ruchy możliwe do wykonania przez każdego, jasne i szeroko rozpowszechniane reguły, zadania, pomysły itp. - mówią same za siebie, w związku $\mathrm{z}$ czym nie ma potrzeby dodatkowego werbalizowania politycznych haseł na scenie (Vujanović 2015).

Po pierwsze, partytury ujawniają proces pracy artystycznej jako ciąg podejmowanych decyzji i stojących za nimi motywacji oraz inspiracji, odsłaniając przy tym logikę pracy danego twórcy czy twórczyni i otwierając dyskusję na temat innych możliwych rozwiązań. 
Partytury, używane wówczas przez artystów awangardowych, w tym Johna Cage’a czy grupę Fluxus, stały się popularne jako narzędzia służące zarówno realizacji spektakli tanecznych, jak i prowadzące do kwestionowania autorytetu autora. Partytura wprowadzała zadania, które miały być wykonane przez performerów - wykluczając w ten sposób takie elementy, jak intuicja, uczucia czy potrzeba „wyrażania siebie”. Jednocześnie detronizowała autora - warto tu wspomnieć symboliczny gest Yvonne Rainer, która wyrzekła się autorstwa Trio A (spektaklu kluczowego zarówno dla jej własnej artystycznej praktyki, jak i dla tańca minimalistycznego w ogóle) w geście do pewnego stopnia inspirowanym Johnem Cage'em: Rainer uznała, że każdy, kto wykonuje Trio A, może i ma prawo dowolnie udostępnić je komukolwiek innemu (Vujanović 2015).

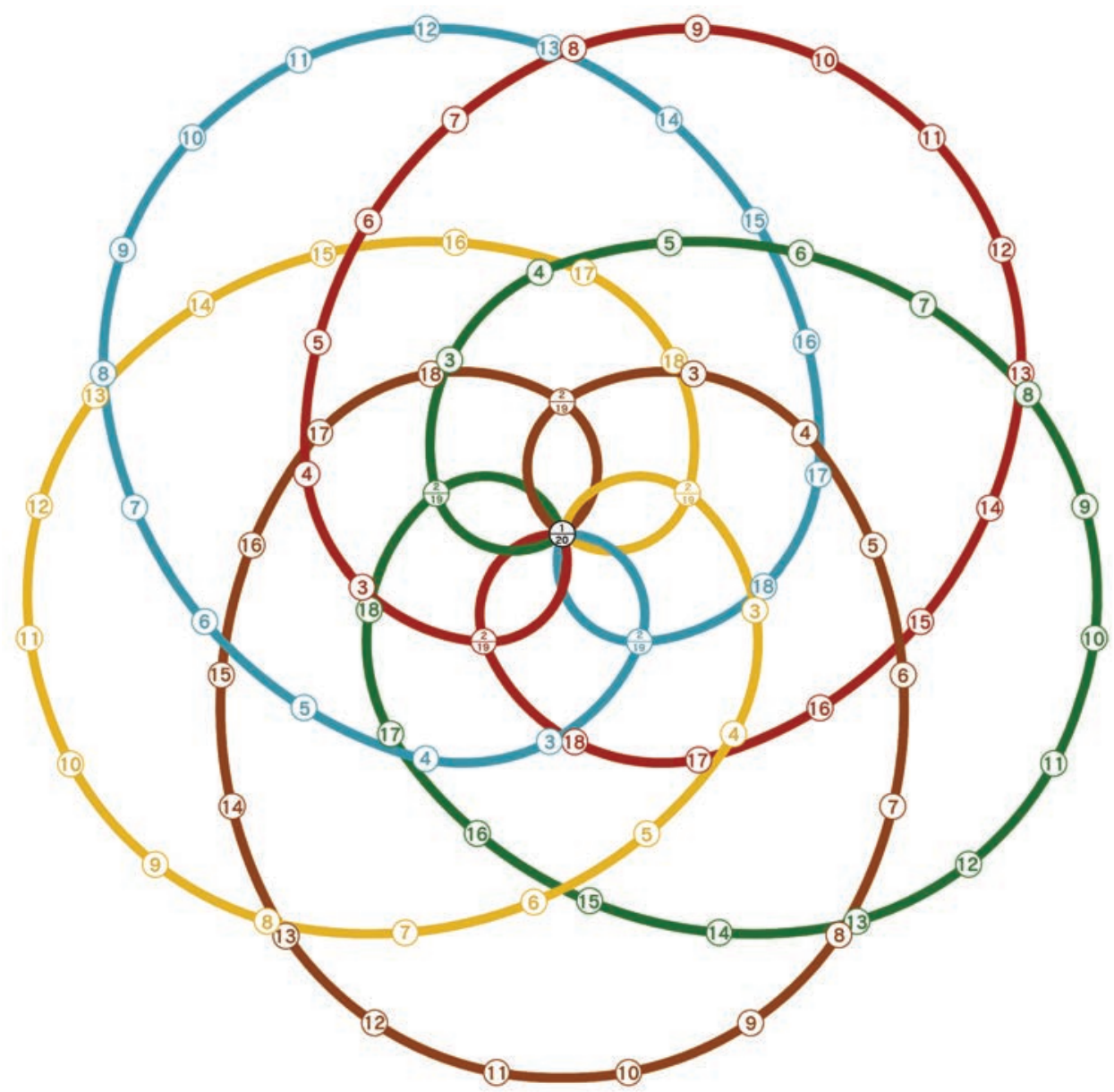

Rys. 1. Score do spektaklu Take It or Make It; koncepcja: Ana Vujanović, premiera: 15 kwietnia 2015 roku, Teatr Polski w Bydgoszczy (materiały teatru) 


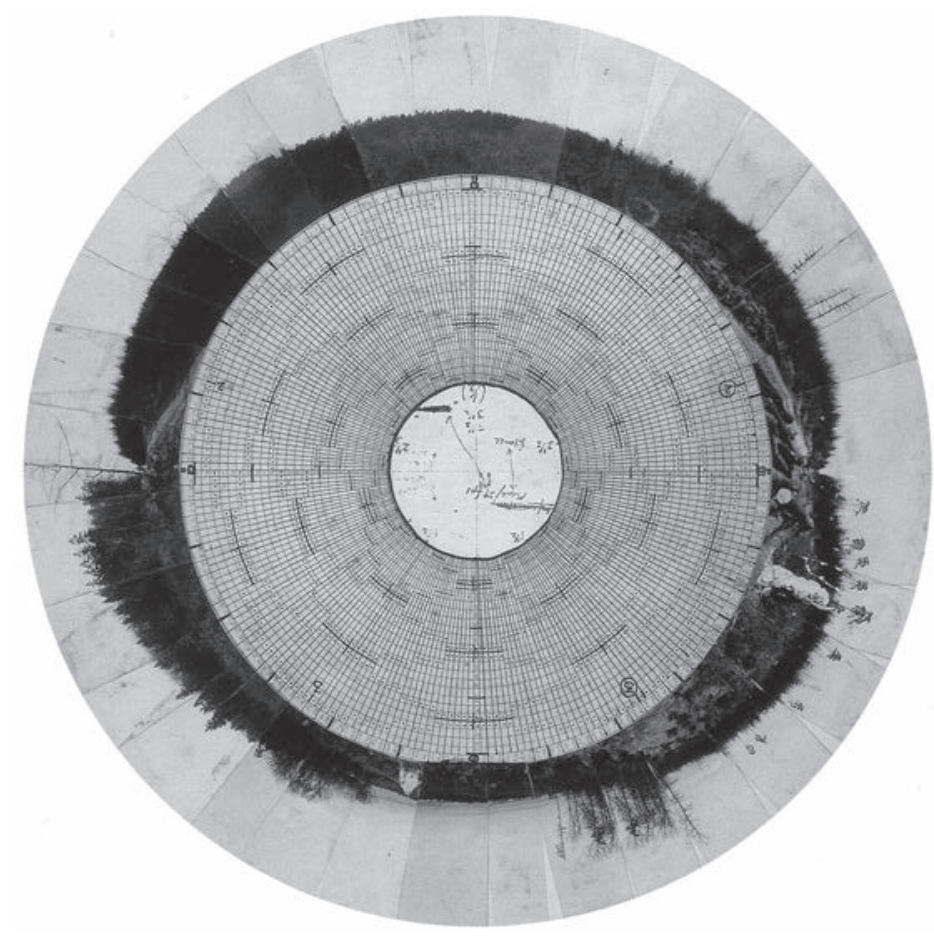

Rys. 2. Score pochodzący z filmowej serii pt. Schenec-Tady Heinza Emigholza Źródło: materiały Teatru Polskiego w Bydgoszczy

Po drugie, partytury umożliwiają każdemu wykonanie danej pracy i rozwinięcie jej w wybraną przez siebie stronę: najczęściej nie wymagają żadnego przygotowania technicznego czy wieloletniej praktyki z ciałem.

Co jednak dla omawianej tu strategii krytycznej szczególnie istotne, partytura Take It or Make It została wybrana przez twórców koncepcji, Anę Vujanović, Martę Popivodę i Sašę Asenticia: aktorzy otrzymali zatem gotową, zewnętrznie narzuconą strukturę i zadanie do wypełnienia. Sytuacja ta nawiązywała do współczesnego sposobu myślenia o demokracji liberalnej, traktowanej często jak zbiór arbitralnie narzuconych regul, które należy wypełnić - widać to doskonale, jak zwraca uwagę Vujanović, na przykładzie procedur przyjmowania nowych państw członkowskich do Unii Europejskiej. Aspirujący kandydaci muszą spełnić określone wymogi i dostosować się do zewnętrznych wyznaczników, by być uznanym za kraj demokratyczny (w rozumieniu urzędników UE); często wymogi te, odgórnie narzucone, nie uwzględniają lokalnego kontekstu czy różnic kulturowych.

Zadanie performerów polegało na znalezieniu własnej logiki wykonania partytury: o ile struktura procesu została im narzucona, o tyle temat, czas trwania i sposób działania były otwarte - pod warunkiem respektowania partytury 
(a więc systemu poruszania się po scenie). Założyliśmy, że score traktowany jest tutaj jak konstytucja: zbiór zasad i reguł porządkujących działania na scenie. Każdy z wykonawców pracował indywidualnie (i pod opieką Vujanović) nad swoim zadaniem - nie informując o swoich wyborach pozostałych. Kiedy po kilku tygodniach performerzy ponownie spotkali się na scenie, ich zadanie polegało na wykonaniu swojej partytury - ale w sposób, który umożliwi innym wykonanie własnych. Założenie to służyło sprawdzeniu, czy możliwe jest funkcjonowanie demokratycznego społeczeństwa w oparciu o zbiór indywidualnych jednostek - a więc $\mathrm{w}$ oparciu o jeden z fundamentów społeczeństwa neoliberalnego. Naturalnie, bardzo szybko okazało się, że wykonanie partytury jest niemożliwe: performerzy wchodzą sobie $\mathrm{w}$ drogę, zagłuszają się, dominują nad pozostałymi bądź nie są słyszani, potrzebują radykalnie odmiennych warunków technicznych (wyciemnienie bądź bardzo jasne oświetlenie), wreszcie - logika wymyślona przez jednego performera nabiera zupełnie innego charakteru i skręca $\mathrm{w}$ nieprzewidzianym kierunku zderzona z logiką drugiego. Kolejne trzy tygodnie pracy polegały przede wszystkim na żmudnych i niejednokrotnie frustrujących negocjacjach. Jako zasadę przyjęliśmy, że stosowane mogą być wyłącznie procedury znane systemowi demokracji przedstawicielskiej, a więc m.in. głosowanie, negocjacje, debaty, kampania na rzecz danej osoby czy sprawy, konsensus, referendum, kompromis, dominacja, naciski rozmaitych i często sprzecznych grup interesów. Podczas premiery dokonywaliśmy przed publicznością odtworzenia procesu negocjacji - tak by mogła w nim uczestniczyć i w ten sposób wpłynąć na przebieg spektaklu.

W mojej opinii gest zastosowania praktyk choreograficznych opartych na partyturze do realizacji spektaklu $\mathrm{w}$ ramach instytucji teatru repertuarowego ujawnił swój polityczny i krytyczny potencjał w kilku obszarach.

Po pierwsze, $\mathrm{w}$ procesie pracy nad spektaklem sproblematyzowane zostały mechanizmy instytucjonalne. Ustanawiając procedury skoncentrowane wokół partytury, podjęliśmy próbę zbadania, czy możliwy jest demokratyczny sposób produkcji sztuki w ramach instytucji teatru repertuarowego, oraz pokazania wiążącego się z tym ryzyka. Jednym z naszych podstawowych celów było przyjrzenie się zasadom, jakie rządzą procesem produkcji sztuki. Pytaliśmy o rolę, znaczenie i odpowiedzialność reżyserki, twórczyni, autorki, zespołu, grupy współpracowników - a więc struktury teatru repertuarowego. Po co? Ponieważ uczciwa postawa krytyczna w teatrze nie jest możliwa bez wyraźnej redefinicji modelu produkcji sztuki, w tym przypadku - zasad, warunków i sposobów teatralnej pracy.

Vujanović zaproponowała dość radykalne podważenie struktury pracy w teatrze. Jej pierwszą decyzją była rezygnacja z pozycji reżyserki czy choreografki. Artystka rozpoczęla pracę nad Take It or Make It od przedstawienia bardzo konkretnej i precyzyjnie przygotowanej propozycji artystycznej, ustanawiającej ramy wspólnej pracy i wyznaczającej zarówno obszar, jak i metodę naszych działań. Własną funkcję określiła jako rukovodilac - akuszerki procesu artystycznego, 
która nie tyle reżyseruje, ile stwarza warunki do wspólnych działań, nadzoruje i wspiera ich przebieg, nadaje im konkretny kierunek oraz bierze za niego odpowiedzialność. Jednocześnie aktorzy i performerzy uczestniczący w projekcie stali się współtwórcami wydarzenia. Tym samym stematyzowana i zakwestionowana została tak częsta w teatrze hierarchia, wedle której aktorzy wykonują instrukcje reżysera. Nie oznacza to jednak, że w trakcie przygotowań do spektaklu tworzyliśmy bezkonfliktową wspólnotę. Przeciwnie - proces pracy zasadzał się na nieustannych negocjacjach, na ciągłej konieczności redefiniowania swoich wyjściowych założeń i indywidualnych wyborów, niejednokrotnie stojących w sprzeczności z decyzjami i potrzebami pozostałych członków zespołu. Co więcej, autonomia działań performerów była możliwa tylko w arbitralnie wyznaczonych granicach, wyrysowanych przez narzuconą partyturę, która zapewniała wykonawcom ramy aktywności, ale nie oferowała podstawowego poczucia bezpieczeństwa: proces pracy renegocjowany był do dnia premiery, a następnie dalej poddawany dyskusji, już w obecności publiczności.

Po drugie, zależało nam na sproblematyzowaniu relacji widza i artysty, odbiorcy i twórcy. Za decyzją o zastosowaniu praktyki choreograficznej opartej na partyturze stała chęć odsłonięcia procesu pracy artystycznej wobec publiczności - uczynienia go materialnym, dotykalnym, uchwytnym. Performerzy ujawniali widzom przebieg pracy nad spektaklem, proces podejmowania decyzji oraz renegocjowali w ich obecności zasady współpracy. Take It or Make It nie było gotowym produktem do zaoferowania, a raczej pokazem i omówieniem procesu pracy. Celem było tu zerwanie z mitem natchnionego artysty i odsłonięcie procedur i motywacji stojących za danymi wyborami.

Wreszcie, poprzez użycie partytury jako jednego z narzędzi demokratyzacji praktyk choreograficznych, spektakl zadawał pytanie o zasady funkcjonowania demokracji. Czy demokracja może działać jako zbiór indywidualności? Czy większość ma prawo narzucić mniejszości własny punkt widzenia, czy raczej to większość powinna chronić prawa mniejszości? Jak można pozwolić każdemu podjąć własną, indywidualną decyzję, podążać własną, indywidualną, wybraną ścieżką i nie być zmuszonym czy zmuszoną do rezygnacji z podstawowych - znowu: własnych - wyborów, założeń? Czy potrzeba spełnienia osobistych potrzeb pozostawia jakąkolwiek przestrzeń dla tego, co wspólne, dla wielości? Czy demokracja przedstawicielska, w której wybierani przez nas politycy mają za zadanie reprezentować nasze interesy, jest jedyną możliwą? Trudno przecież mówić o zachowaniu podstawowych zasad demokracji w sytuacji, kiedy społeczeństwo nie ma żadnego realnego wpływu na decyzje rządzących, które bezpośrednio tego społeczeństwa dotyczą.

Struktura Take It or Make It zbudowana jest wokół pytania o proces podejmowania decyzji i brania za nie odpowiedzialności. W trakcie pracy dotknęliśmy ważnego paradoksu: demokracja może funkcjonować tak długo, jak wszyscy jej uczestnicy akceptują demokratyczne zasady i metody podejmowania decyzji; jak 
tylko pojawia się ktoś, kto zamierza naruszać zasady demokratyczne, demokracja nie ma narzędzi, by się obronić. I wreszcie ostatnie z pytań, które stawialiśmy w spektaklu: czy demokracja jest raczej porządkiem narzuconym, podobnie jak partytura w naszym przypadku, czy to my decydujemy o zasadach demokratycznego porządku?

I chociaż Take It or Make It nie podaje rozwiązań, a jedynie bada reguły demokratyczne i ujawnia ich ograniczenia, to, jak wierzę, pokazuje, że krytyczny potencjał instytucji tkwi właśnie w momencie wytwarzania sztuki, a poszukiwanie jej politycznego potencjału nie będzie wiarygodne w oderwaniu od namysłu nad warunkami, w jakich powstaje. Wydaje się, że sztuki performatywne są szczególnie ciekawym polem takich badań - stanowią przecież praktykę społeczną, której zasady są ciągle ustalane od początku i redefiniowane, każdego wieczoru od nowa.

\section{Bibliografia}

Banes S. (1993), Democracy's Body. Judson Dance Theater, 1962-1964, Duke University Press, Durham-Londyn.

Banes S. (2013), Terpsychora $w$ tenisówkach. Taniec post-modern, tłum. A. Grabowski, J. Majewska, PWM, Kraków.

Cvejić B. (2015), Podłaczanie widza w „Untitled” Xaviera Le Roy, http://20.konfrontacje. $\mathrm{pl} / 2015 / 09 / 07 /$ bojana-cvejic-podlaczanie-widza-w-untitled-xaviera-le-roya/ (dostęp: 24.07.2017).

Klimczyk W. (2015) Wirus mobilizacji. Taniec i ksztattowanie się nowoczesności, Universitas, Kraków.

Vujanović A. (2013), Notes of the Politicality of Contemporary Dance, [w:] S. Hölscher, G. Siegmund (red.), Dance, Politics \& Co-Immunity, Diaphanes, Zürich-Berlin.

Vujanović A. (2015), Polityka formy $w$ tańcu: o partyturach [score'ach] i demokratyzacji tańca, tłum. J. Kurek, (red.) M. Keil, program spektaklu Teatru Polskiego w Bydgoszczy Take it or Make it (premiera: 15 kwietnia 2015), http:/ /www.taniecpolska. pl/przedruk/339 (dostęp: 10.06.2017).

\section{Summary}

Is it possible to study the mechanisms of modern democracy by choreographic practice? Drawing on the experience of curatorial and dramaturgical work on Ana Vujanovićs Take It or Make It performance, which was completed in April 2015 at the Teatr Polski im. Hieronima Konieczki in Bydgoszcz, I will propose recognizing choreography as a political practice that requires artistic and experimental testing of various social models, looking at the process of production and re-thinking its structures and internal relationships of power. I will present the way choreography can problematize the position of an artist and a viewer and serve as a tool for institutional critique within the repertoire theater. 